\title{
The Impact of Internet Experience and Attitude on Student Preference for Blended Learning
}

\author{
Majed Gharmallah Alzahrani ${ }^{1, *}$ \& John Mitchell O’Toole ${ }^{2}$ \\ ${ }^{1}$ Faculty of Education, University of Jeddah, Jeddah, Saudi Arabia \\ 2 School of Education, Faculty of Education and Arts, University of Newcastle, Newcastle, NSW, Australia \\ *Correspondence: Faculty of Education, University of Jeddah, 21454, P.O.BOX: 15758, Jeddah, Saudi Arabia. \\ E-mail: mgalzahrani@uj.edu.sa
}

Received: February 15, 2017

Accepted: March 9, 2017 Online Published: March 22, 2017

doi:10.5430/jct.v6n1p65

URL: https://doi.org/10.5430/jct.v6n1p65

\begin{abstract}
The purpose of this study is to investigate student experience with the Internet, and their attitudes towards using it, in an attempt to determine the impact of these experiences and attitudes on their view of the implementation of blended learning. Data from 142 Saudi students at a leading university in Saudi Arabia were collected via an online questionnaire. The results reveal that students have both experience with and positive attitudes towards using the Internet. Demographic variables had no effect on these attitudes, but experience variables showed significant effects. Interestingly, there were mixed interactions regarding student study year; negatively with Internet experience and positively with preference for the implementation of blended learning. Neither experience with the Internet nor program of study appeared to influence student preference for blended learning but age, study year, and attitudes towards the Internet were associated with positive attitudes towards blended learning. Importantly, students in the present study supported the implementation of blended learning, but not entirely online learning. Student attitudes towards the Internet in general appeared to influence their attitude to learning approaches that use the Internet in blended learning environments. Discussion of these results is presented with suggested implications.
\end{abstract}

Keywords: attitudes, the Internet, blended learning, higher education, Saudi Arabia

\section{Introduction}

In Saudi Arabia, the Internet became officially available to the public in 1999 (Simsim, 2011), and the number of users has increased dramatically since that time. For example, the Communications and Information Technology Commission (2009) reported that the proportion of the Internet users in the Saudi Arabian higher education context has jumped from $25 \%$ in 2007 to 39\% in 2008. Recent studies have indicated that the Internet is considered important element for teaching and learning within Saudi Arabian higher education (Aldebasi \& Ahmed, 2013; Alshawi \& Alwabil, 2013). Ready adoption of new technologies by young people in Saudi Arabia may undergird the rapid increased of Internet users (Alebaikan \& Troudi, 2010a), making university students more likely to adopt new learning approaches such as blended learning.

\section{Literature Review}

The following sections outline existing work on the Internet experience of university students and their attitudes to both the Internet and varying learning approaches. The following discussion also explores relationships between these dimensions.

\subsection{Experience with, and Attitudes towards, the Internet}

Research in the Saudi higher education context has shown that university students generally have access to the Internet at home (Al Otaibi, 2012; Aldebasi \& Ahmed, 2013; Ali, 2013; Almalki, 2011), but that such access is more limited for female students (Alebaikan, 2010; Alhareth, 2013; Miliany, 2014). Such domestic Internet access may have a positive impact on student attitudes towards the Internet. For example, Al Otaibi (2012) found that home Internet access had a more significant and positive relationship with students' use of, and general attitudes towards, 
the Internet than Internet café access. Moreover, at Baysal University in Turkey, Tekynarslan (2008) found that students who have home Internet access had significantly more positive attitudes toward the Internet than students who do not have Internet access at home. Most importantly, students who had home Internet access were found to positively perceive online education (Al-Arfaj, 2001; Alaugab, 2007).

The current study follows previous work in defining prior experience with using the Internet as the length of time between first student Internet access and the time of responding to the current study (Luan, Fung, Nawawi, \& Hong, 2005). In this instance, Tsai, Lin, \& Tsai (2001) found that about half of the Taiwanese high school students in their study (42\%) had used the Internet for less than one year, more than quarter of them (36\%) had used it for 1 to 2 years, one fifth of them (20\%) had used it for 2 to 4 years, and a tiny portion of them (2\%) had used it for more than 4 years. In the Saudi higher education context, Oshan and Khudair (2008) found that more than one fifth of the 790 participating students (21.9\%) had used the Internet for less than one year, $15.44 \%$ used it from 1 to 2 years, and almost half of them (45.82\%) had used it for more than two years. More recently, Ali (2013) investigated Internet usage among students at Jazan University. He found that less than one-third of participating students (30\%) had used it for less than one year, one-third (33\%) had used it for 1-4 years, and slightly more (37\%) had used it for more than 4 years. Most importantly, previous studies have indicated that student greater Internet experience has a substantial positive effect on their attitudes towards the Internet (Al Mahmud, 2011; Al Otaibi, 2012; Oshan \& Khudair, 2008; Tekynarslan, 2008; Tsai et al., 2001).

A great deal of attention has been paid to attitudes to Internet tools as they are increasingly used to deliver instruction to a wide range of students in an attempt to attract and retain them in institutions of higher education (Wiebe, Shaver, \& Wogalter, 2002). Student attitudes may affect their performance on such Internet tools and impact future introduction of information and communications technology (ICT) materials in education (Abedalaziz, Jamaluddin, \& Leng, 2013). Positive attitudes towards the Internet "contribute to the increase in the success of learning activities" (Tuncer, Dogan, \& Tanas, 2013, p. 1307) which considered as "a prerequisite for successful Internet-based instruction" (Wu \& Tsai, 2006, p. 441). Consequently, a number of scales have been designed to examine student attitude to Internet use (see e.g. Duggan, Hess, Morgan, Kim, \& Wilson, 1999, 2001; Morse, Gullekson, Morris, \& Popovich, 2011; Tsai et al., 2001; Zhang, 2007).

Generally positive university student attitudes to the Internet appear in Taiwan with undergraduate and graduate students (Chou, Wu, \& Chen, 2011; Peng, Tsai, \& Wu, 2006): in Malaysia with undergraduates (Hong, Ridzuan, \& Kuek, 2003; Luan et al., 2005) and postgraduates (Abedalaziz et al., 2013): in Pakistan with university students (Rehman, Hunjra, Safwan, \& Ahmad, 2010); in Bangladesh with graduate and postgraduate students (Al Mahmud, 2011); in Nigeria with undergraduates (2013); and finally in Saudi Arabia with teachers college students (Al Otaibi, 2012). Students respond positively to the Internet as a functional technology (Peng et al., 2006), a learning tool (Al Mahmud, 2011; Hong et al., 2003), and a provider of substantial information (Rehman et al., 2010).

Student background variables appear to have varying impact on student attitudes to the Internet. Abedalaziz et al. (2013) found that younger Malaysian students had significantly more positive attitudes than older students but this did not hold for the Turkish context (Tuncer et al., 2013). Conversely, Peng et al. (2006) found "students at the advanced-grade level had a stronger tendency to appreciate the potential usefulness of the Internet, express more positive feelings towards the Internet and frequently use the Internet than students at the lower-grade level” (p. 79) and Chou et al. (2011) found that participating graduate students had a more positive attitude toward the Internet than did undergraduate students in general, but that grade levels made no significant difference to the attitudes of undergraduate students, a finding echoed by Tuncer et al. (2013). Hong et al. (2003) found that undergraduate students studying in technology-related faculties were significantly more positive about the Internet than students studying at the Faculty of Cognitive Sciences and Human Development. Similarly, significant differences were found based on field of study of undergraduate student by Tuncer et al. (2013). However, Abedalaziz et al. (2013) found similarly positive postgraduate Internet attitudes, regardless student program of study.

Student experience with the Internet has a more consistent impact on their attitudes. For example, Hong et al. (2003) found undergraduates who had better basic Internet skills preferred using the Internet for learning. Previous research also indicated a positive relationship between the usage rate of the Internet and the student attitudes towards it (Al Mahmud, 2011; Al Otaibi, 2012; Luan et al., 2005), where usage rate is defined as "the number of hours the user spends on the Internet” (Al Otaibi, 2012, p. 152). This possible relationship may eventually have a positive impact on students learning as the majority of students used the Internet for entertainment and educational purposes. 


\subsection{Learning Approaches with Focus on Blended Learning}

Three major learning approaches are presented in the present study, traditional learning, online learning, and blended learning. Traditional learning involves the presence of both lecturer and learners in the same physical space. This is also known as the face to face (F2F) classroom. Such face to face lectures dominate the higher education context in Saudi Arabia (Ageel, 2011; Al-Zahrani, 2015; Alebaikan \& Troudi, 2010a). The second approach is online learning which involves the use of electronic technology, specifically the Internet, to fully convey information to the learner in different physical spaces. Finally, blended learning combines traditional and online learning in an attempt to utilise the strengths of each while avoiding associated weaknesses.

Blended learning, also known as hybrid learning and mixed learning, is a broad concept that can be variously defined across many dimensions. Graham (2006, 2008) identified three major categories of blended learning: enabling blends, enhancing blends, and transforming blends. This study relates to the first category, that is, enabling blends which "primarily focus on addressing issues of access and convenience-for example, blends that are intended to provide additional flexibility to the learners or blends that attempt to provide the same opportunities or learning experience but through a different modality” (Graham, 2006, p. 13).

Such blended learning tries to reduce the traditional learning time by including some online learning components. Pedagogically, blended learning could be the best solution for improving higher education in many countries including Saudi Arabia. Garrison and Vaughan (2008) stated that blended learning "addresses the issue of quality of teaching and learning. It is an opportunity to address pressing pedagogical concerns, while distinguishing and enhancing the reputation of institutions of higher education as innovative and quality learning institutions” (p. 153). According to the Güzer and Caner (2014) review and analysis of the 28 most frequently cited articles/books from Google Scholar on blended learning that were published from 1999 to 2012, blended learning is perceived as useful, enjoyable, supportive, flexible and a motivator of students. The implementation of blended learning is at an early stage in Saudi universities (Alebaikan, 2010; Almalki, 2011; Alshahrani \& Ward, 2014) and so a fresh consideration of student attitudes to it seems timely.

There is some previous research and it reveals generally positive student attitudes towards blended learning in Saudi Arabia (AlAbdulkarim \& Albarrak, 2015; Alebaikan, 2010; Alseweed, 2013; Ja'ashan, 2015) and elsewhere (Shantakumari \& Sajith, 2015). Moreover, it was found that students preferred blended learning over traditional or completely online learning environments in contexts as diverse as the United States (Tang \& Byrne, 2007), Slovenia (Lukman \& Krajnc, 2012), and Saudi Arabia (Alseweed, 2013; Mohandes, Dawoud, Amoudi, \& Hussain, 2006). Most importantly, Shantakumari and Sajith (2015) found no correlation between age and student perceptions of blended learning, in the United Arab Emirates, but there was a significant correlation between their perceptions and course enrolment. The authors attributed these differences to the possible difference in the duration and percentage of the online component of courses.

\section{Objectives of the Study and Research Questions}

The previous section indicated some disagreement about the impact of background variables, such as grade level and discipline, on student attitudes to the Internet. The present study will investigate Saudi undergraduate attitudes to blended learning and explore the impact of student background variables on those more tightly focussed attitudes. In particular, the current study addresses the following research questions:

Q1- What Internet experience do students have?

Q2- What are student attitudes towards the Internet?

Q3- Are there any statistical differences between student experiences and attitudes based on study years?

Q4- Do students favour the implementation of blended learning?

Q5- What are the relationships between student demographics, experience with using the Internet, and attitudes towards the Internet to their preference of blended learning?

\section{Methodology}

\subsection{Design}

A survey research design was employed to collect the data required for the present study. According to Creswell (2012), survey research designs are "procedures in quantitative research in which investigators administer a survey to a sample or to the entire population of people to describe the attitudes, opinions, behaviours, or characteristics of the 
population” (p. 376). The present study utilised a cross-sectional design where the data were collected at one point in time in order to examine current student experience with, and attitudes towards, the Internet and their preferences for learning approaches. The online questionnaire designed for this study will be described in the instrument section.

\subsection{Sampling}

Male students studying within the Faculty of Education at one of the leading public universities in the Western Region of Saudi Arabia formed the sample for this study. The exclusion of female students was due to local cultural and religious restrictions (e.g., see Madini \& de Nooy, 2014; Robertson \& Al-Zahrani, 2012). In order to investigate anticipated differences in student use of the Internet, this study targeted students who were enrolled in the first and fourth years of study. Enrolling Faculty of Education undergraduate students have studied basic computer skills at the secondary education level while those in the fourth year have added further information technology courses. The varying Internet skills may reveal a variety of perspectives.

The questionnaire was mounted on the www.suwet.com and students from years one and four of the initial teacher education program were invited to participate (a possible total of 265 students). Completion of the online questionnaire was anonymous and there was no way to identify the author of specific responses. Students who did not wish to participate were informed that they could close the Internet browser at any time, but responses could not be eliminated once submitted.

One hundred and sixty-two (162) online questionnaires were submitted, twenty of which had missing data and were consequently excluded. Ultimately, 142 male Saudi pre-service teachers completed the online questionnaire. The response rate of the completed online questionnaire was 53.6\% (142/265).

\subsection{Instrument}

The instrument for this study comprised three major sections. The first section elicited student background information including age, specialisation, and year of study. The following section dealt with student experience with the Internet, and their attitude towards it. The final section sought student preferences of learning approaches and comments about any pertinent issue. Items on the second and final sections were closed questions requiring mostly a response on a conventional five-point Likert scale.

The construction of the instrument benefited from previous studies. Items related to student background information as well as Internet experience were drawn from Luan et al. (2005), and some related to attitude were drawn from Tsai et al. (2001), which was originally developed for high school students before subsequent use with university students (e.g., see Abedalaziz et al., 2013; Luan et al., 2005; Oshan \& Khudair, 2008; Peng et al., 2006). The Internet attitude scale comprised four subscales; perceived usefulness, affection, perceived control, and behaviour. It should be noted the behaviour scale in the original attitudes instrument had three items, as opposed to five items for the other three scales, and so an additional two behaviour items were added to the present instrument (see Table 2). The Cronbach alpha coefficient calculated for the entire attitude scale was 0.76 suggesting that it can be considered reliable (Field, 2009; Muijs, 2004; Pallant, 2011). The original scale yielded slightly higher Cronbach alpha reliability coefficients of 0.81 (Tsai et al., 2001) and 0.80 (Oshan and Khudair 2008) but Luan et al. (2005) reported a Cronbach alpha coefficient value that was similar to the current study after removing three items from the original attitudes scale. No subscale results are reported in this paper, as the focus is on general student Internet attitudes. In regard to the student preferences of learning approaches, four items were developed and revised by educational technology experts to ensure their accuracy yielded a Cronbach alpha coefficient of 0.69 , which remains acceptable although lower than the attitude scale as a whole.

The questionnaire used in this study was presented in Arabic, with items translated from the English text found in the literature. Translated items conformed to conventional clarity and simplicity criteria (Creswell, 2012; Dörnyei, 2003). Three bilingual academic staff members and an English teacher were involved in the double back translation work. One of them translated the questionnaire into Arabic, and the other changed it back into English, and the last two compared their translations to ensure that the questions have the same meaning. According to Susan (2000) such double translation is commonly used to validate the translation process and it should ensure that the translation of the questionnaire is accurate and valid.

\subsection{Administration of the Online Questionnaire}

Information statements containing a given link and a password were distributed to students by the first author. Those students who were willing to participate were also invited to complete the online questionnaire at computer labs within the faculty. This process ensured that each student was given an opportunity to complete the online questionnaire, regardless of home Internet connection. This process also reduced the likelihood of multiple online 
questionnaire completions by a single student. Since the questionnaire was commercially hosted online, access was password protected to ensure that no responses were received out of the intended sample.

\subsection{Analysis Procedures}

The Statistical Package for Social Sciences (SPSS v.20.0 package) was used to analyse the quantitative data. The small amount of text gathered through the open-ended question at the end of the online questionnaire allowed the qualitative data to be analysed manually. The quantitative data were initially downloaded electronically into an Excel file and then coded and entered to the SPSS file. Descriptive analyses were performed to describe the background information and the Internet experience of the participating students. Means were calculated to measure the central tendency of the student attitudes to using the Internet and a series of statistical tests, including the independent samples t-test and the one-way analyses of variance (ANOVA), were performed to examine the differences between participating students. The post-hoc, Scheffe test, was used to ascertain which groups actually differed when significant differences between participating students were found (Muijs, 2004). Finally, correlational analyses, including bivariate correlation and regression analyses, were performed to explore the relationships between the study variables.

Assumptions of parametric tests, including independency, normality, and homogeneity (Field, 2009), were checked to ensure that they were not violated. The procedures described in the administration of the online questionnaire, in which participants in the online questionnaire were assigned individually, could assume the independence of the gathered data. The sample size of the current study satisfied the assumption of normality (Field, 2009; Pallant, 2011). The homogeneity assumption was not violated in general: Levene's test was not significant $(>.05)$ in the attitude scale, confirming that the variance was equal across the different age groups $F(7,133)=.930, p=.382$, and across the different length of time using the Internet groups $F(5,136)=10.314, p=.97$.

The current study accepted a significance level of .05 (Field, 2009), which is commonly used in educational research (Johnson \& Christensen, 2014).

\section{Results}

\subsection{Background Information}

Participating students were Saudi, male, full-time students, ranging in age from 19 to 27 years with mean of 22.11 years old. The majority ( $n=85,59.9 \%)$ were enrolled in the fourth year of study with a fewer number enrolled in the first year of study ( $n=57,40.1 \%$ ). Distribution of students among academic specialisations was as follows: $0.7 \%$ Arabic, 5.5\% Science, 9.0\% Mathematics, 12.4\% English, 13.1\% Computer, 15.2\% Qur'anic Studies, and 42.1\% Special Education.

\subsection{Experience with Using the Internet}

Table 1 reveals that the majority of students (88.7\%) had home Internet access and that most (96.5\%) reported that they were experienced with using the Internet, although five students enrolled in the fourth year of study reported that they had no experience. The data in Table 1 also shows that the majority of students had used the Internet for three years or more (69.7\%). Five students had no experience with using the Internet and consequently the length of using the Internet question was not applicable to them.

Table 1. Experience with Using the Internet

\begin{tabular}{lcr}
\hline \multicolumn{1}{c}{ Item } & Responses & \multicolumn{1}{c}{$\mathbf{N ~ ( \% )}$} \\
\hline \multirow{2}{*}{ The Internet access at home } & Yes & $126(88.7)$ \\
& No & $16(11.3)$ \\
\hline \multirow{2}{*}{ Experience with using the Internet } & Yes & $137(96.5)$ \\
& No & $5(3.5)$ \\
\hline \multirow{3}{*}{ Length of time using the Internet } & NA & $5(3.5)$ \\
& $<1$ year & $4(2.8)$ \\
& $1<2$ years & $14(9.9)$ \\
& $2<3$ years & $20(14.1)$ \\
& 3 to 4 years & $34(23.9)$ \\
& $>4$ years & $65(45.8)$ \\
\hline
\end{tabular}


The Independent Samples t-test indicated that both student groups, first year and fourth year, had similar access to the Internet at home $(t(123.925)=.229, p>.05)$ but that students in the first year of study were significantly more experienced with using the Internet than those in their fourth year of study $(t(84.00)=2.291, p<.05)$. However, the results of the ANOVA test revealed that students had similar expertise with using the Internet regardless of the different lengths of time they have reported $(F(1,141)=1.979, p>.05)$.

\subsection{Student Attitudes towards the Internet}

Generally, students seemed to have a positive attitude toward the Internet (see Table 2), which indicates that the overall mean values of the 20 items ranged between 1.93 and 4.53 and that the overall value of the entire scale had a mean and standard deviation of $(N=142, M=3.77, S D=0.4)$.

Table 2. Student Internet Attitudes

\begin{tabular}{|c|c|}
\hline Item & M (SD) \\
\hline The Internet makes a great contribution to human life & $4.50(.616)$ \\
\hline The Internet makes society more civilized & $4.53(.555)$ \\
\hline I hesitate to use the Internet in case I look illiterate* & $3.99(1.024)$ \\
\hline The Internet helps me acquire relevant information I need & $4.53(.627)$ \\
\hline The Internet can allow me to do more creative work & $4.37(.75)$ \\
\hline If given the opportunity to use the Internet, I am afraid that I might abuse it in some way* & $3.13(1.19)$ \\
\hline The Internet enlarges my scope & $4.27(.675)$ \\
\hline I could probably teach myself most of the things I need to know about the Internet & $4.18(.701)$ \\
\hline The Internet makes me feel uncomfortable* & $3.87(.998)$ \\
\hline I can use the Internet independently, without the assistance of others & $4.15(.96)$ \\
\hline I do not need someone to tell me the best way to use the Internet & $3.18(1.171)$ \\
\hline When using the Internet, I am not quite confident about what I am doing* & $3.73(.93)$ \\
\hline If I have problems using the Internet, I can usually solve them one way or the other & $3.79(.874)$ \\
\hline I use the Internet regularly at the university & 2.70 (1.19) \\
\hline I feel bored when using the Internet* & $3.75(1.021)$ \\
\hline I spend a lot of time using the Internet & $3.65(1.136)$ \\
\hline I use the Internet rather than reading books** & $3.77(1.157)$ \\
\hline I need an experienced person nearby when I use the Internet* & $3.30(1.238)$ \\
\hline I use the Internet in many ways in my life** & $4.13(.736)$ \\
\hline I only use the Internet at university when told to* & $1.93(.888)$ \\
\hline Total & $3.77(.4)$ \\
\hline
\end{tabular}

* Reversed. ** Additional items.

\subsection{Attitude towards the Internet Comparisons based on Demographic and Experience Variables}

ANOVA results reveal that students had similar attitudes towards the Internet based on their age $(F(8,133)=.930$, $p>.05)$ but that they had different attitudes towards the Internet based on the program of study $(F(6,135)=2.561, p$ $<.05$ ), but the Scheffe test suggested that all students had similar attitudes towards the Internet regardless the program of study (see Table 3). The Independent Samples t-test indicated that students in first and fourth years of study had no statistical differences on their attitudes towards the Internet $(t(140)=-.395, p>.05)$ with mean and standard deviation of ( $n=57, M=3.76, S D=0.383)$ and $(n=85, M=3.78, S D=0.412)$, respectively. 
Table 3. Student Internet Attitudes based on Program of Study

\begin{tabular}{|c|c|c|c|c|c|}
\hline \multirow{2}{*}{ Item } & \multirow{2}{*}{ Responses } & \multirow{2}{*}{ N (\%) } & Scheffe test subset for alpha $=0.05^{* *}$ & \multirow{2}{*}{$\mathbf{F}$} & \multirow{2}{*}{$\mathbf{P}$} \\
\hline & & & 1 & & \\
\hline \multirow{7}{*}{$\begin{array}{l}\text { Program of } \\
\text { study }\end{array}$} & Arabic Language & $1(0.7)$ & 3.10 & \multirow{7}{*}{2.561} & \multirow{7}{*}{$.022 *$} \\
\hline & Science & $8(5.6)$ & 3.66 & & \\
\hline & Mathematics & $13(9.2)$ & 3.69 & & \\
\hline & Special Education & $61(43.0)$ & 3.71 & & \\
\hline & Quran Studies & $22(15.5)$ & 3.74 & & \\
\hline & English Language & $18(12.7)$ & 3.94 & & \\
\hline & Computer & 19 (13.4) & 3.99 & & \\
\hline
\end{tabular}

$* P<.05 * *$ The Scheffe test was performed after excluding the single case studying Arabic Language program.

In regard to the experience variables (Table 4), Independent Samples t-tests revealed that students who have home Internet access had significantly higher positive attitudes to using the Internet $(t(140)=-3.352, p<.05)$ and that students who have reported that they have experience with using the Internet had significantly higher positive attitudes towards using it $(t(140)=-4.039, p<.05)$.

Table 4. Student Internet Attitudes based on Home Access and Experience with Using the Internet

\begin{tabular}{lcccc}
\hline \multicolumn{1}{c}{ Item } & Responses & $\mathbf{N}(\mathbf{\%})$ & M (SD) & p \\
\hline \multirow{2}{*}{ The Internet access at home } & Yes & $126(88.7)$ & $3.81(.389)$ & $.001^{*}$ \\
\hline \multirow{2}{*}{ Experience with using the Internet } & No & $16(11.3)$ & $3.47(.356)$ & \\
& Yes & $137(96.5)$ & $3.80(.380)$ & $.000^{*}$ \\
$* P<.05$ & No & $5(3.5)$ & $3.10(.359)$ & \\
\end{tabular}

In regard to the length of time using the Internet (Table 5), ANOVA and the Scheffe test revealed that students who have used the Internet for a longer time had significantly higher positive attitudes towards the Internet $(F(5,136)=$ $10.314, p<.05)$.

Table 5. Student Internet Attitudes based on the Length of Time Using the Internet

\begin{tabular}{|c|c|c|c|c|c|c|c|}
\hline \multirow{2}{*}{ Item } & \multirow{2}{*}{ Responses } & \multirow{2}{*}{ N (\%) } & \multicolumn{3}{|c|}{ Scheffe test subset for alpha $=\mathbf{0 . 0 5}$} & \multirow{2}{*}{$\mathbf{F}$} & \multirow{2}{*}{$\mathbf{P}$} \\
\hline & & & 1 & 2 & 3 & & \\
\hline \multirow{6}{*}{$\begin{array}{l}\text { Length of } \\
\text { time using } \\
\text { the Internet }\end{array}$} & NA & $5(3.5)$ & 3.10 & & & \multirow{6}{*}{10.314} & \multirow{6}{*}{$.000 *$} \\
\hline & < 1 year & $4(2.8)$ & 3.39 & 3.39 & & & \\
\hline & $1<2$ years & 14 (9.9) & 3.58 & 3.58 & 3.58 & & \\
\hline & $2<3$ years & $20(14.1)$ & 3.59 & 3.59 & 3.59 & & \\
\hline & 3 to 4 years & 34 (23.9) & & 3.76 & 3.76 & & \\
\hline & $>4$ years & $65(45.8)$ & & & 3.95 & & \\
\hline
\end{tabular}

$$
* P<.05
$$

\subsection{Student Preferences of Learning Approaches}

The data in Table 6 shows no statistical differences between first and fourth year students in preference for traditional learning and online learning but the fourth year students in particular appeared to prefer studying through blended learning $(t(97.667)=-2.328, p<.05)$. Participating students appeared to prefer blended learning courses that divided their time evenly between face to face (F2F) and online components. 
Table 6. Student Preferences of Learning Approaches

\begin{tabular}{lcccc}
\hline \multicolumn{1}{c}{ Item } & $\begin{array}{c}\mathbf{1}^{\text {st }} \text { year } \\
(n=57)\end{array}$ & $\begin{array}{c}\mathbf{4}^{\text {th }} \text { year } \\
(n=85)\end{array}$ & $\begin{array}{c}\text { Total** } \\
(N=142)\end{array}$ & P \\
\cline { 2 - 4 } & $\mathbf{M}(\mathbf{S D})$ & $\mathbf{M}(\mathbf{S D})$ & M (SD) \\
\hline $\begin{array}{l}\text { I would like to study through the blended learning } \\
\text { courses (F2F classrooms and online learning) }\end{array}$ & $3.33(1.286)$ & $3.80(.973)$ & $3.61(1.129)$ & $.02 *$ \\
$\begin{array}{l}\text { I prefer to spend most of time in F2F classrooms rather } \\
\text { than online learning }\end{array}$ & $3.02(1.203)$ & $2.81(1.200)$ & $2.89(1.201)$ & ns. \\
$\begin{array}{l}\text { I prefer to spend most time in online learning rather } \\
\text { than F2F classrooms }\end{array}$ & $2.84(1.146)$ & $3.22(1.219)$ & $3.07(1.201)$ & ns. \\
$\begin{array}{l}\text { I prefer 50\% of the course in F2F classrooms and 50\% } \\
\text { via the Internet }\end{array}$ & $3.28(1.292)$ & $3.48(1.019)$ & $3.40(1.136)$ & ns. \\
\hline
\end{tabular}

$* P<.05 * *$ The totals are for each item across the two different study years.

\subsection{Students Comments}

Fifty (50) of the 142 participating students wrote comments in response to the open question at the end of the online questionnaire. These comments were categorised as follows. A number of students reported that traditional learning and online learning must be blended $(n=7)$, while others asserted that traditional learning methods are dominant $(n$ $=8)$. Some students reported that the number of computer labs within the faculty is very limited $(n=8)$ and that the available computers labs are not fully equipped $(n=9)$. Finally, some also suggested the Internet connections in the computer labs and within faculty buildings should be supplemented $(n=8)$.

\subsection{Relationships between the Study Variables and Student Preference of Blended Learning}

A bivariate correlation analysis revealed that older students in the fourth year of study were more positive about the Internet and more positive about implementing blended learning (see Table 7). However, the relationships between student program of study, home access or Internet experience and student preference for implementation of blended learning were not significant. Although all significant correlations could be considered slight (Brace, Kemp, \& Snelgar, 2006; Cohen, 1988), it should be noted that the more positive attitudes to the Internet had the highest significant correlation.

Table 7. Significant Correlations with Student Preference of Blended Learning

\begin{tabular}{|c|c|c|c|}
\hline Item & Age & Study year & $\begin{array}{l}\text { Attitude toward the } \\
\text { Internet }\end{array}$ \\
\hline $\begin{array}{l}\text { I would like to study through the blended learning } \\
\text { courses (F2F classrooms and online learning) }\end{array}$ & $.22 *$ & $.20 *$ & $.27^{*}$ \\
\hline
\end{tabular}

A linear regression analysis was performed using the enter method to determine any relationship between the study variables and student preference for blended learning (see Table 8).

A significant model emerged, $\left(F_{7,134}=2.494, p<.05\right)$ with $R^{2}=0.115$, explaining $11.5 \%$ of the variance in student preference of blended learning by differences in age, specialisation, year at university, home Internet access, experience with using the Internet, length of using the Internet, and attitudes towards the Internet. However, not all variables contributed significantly $(p>.05)$ to the student preference for blended learning. It should be noted that student attitudes to the Internet had the highest direct contribution value $(\beta=.20)$ with $p=.05$. 
Table 8. The Relationships between the Study Variables and Student Preference of Blended Learning

\begin{tabular}{|c|c|c|c|c|c|c|c|}
\hline \multirow[t]{2}{*}{ Independent variable } & \multirow{2}{*}{$\begin{array}{c}\text { Dependent } \\
\text { variable }\end{array}$} & \multicolumn{2}{|c|}{$\begin{array}{c}\text { Unstandardized } \\
\text { Coefficients }\end{array}$} & \multirow{2}{*}{$\begin{array}{c}\begin{array}{c}\text { Standardized } \\
\text { Coefficients }\end{array} \\
\text { B }\end{array}$} & \multirow[t]{2}{*}{$\mathbf{t}$} & \multirow[t]{2}{*}{ Sig } & \multirow[t]{2}{*}{$\mathbf{R}^{2}$} \\
\hline & & B & Std.Error & & & & \\
\hline Age & \multirow{7}{*}{$\begin{array}{c}\text { Student } \\
\text { preference of } \\
\text { blended } \\
\text { learning }\end{array}$} & .084 & .060 & .138 & 1.399 & .164 & \\
\hline Program study & & .002 & .046 & .004 & .044 & .965 & \\
\hline Year at university & & .103 & .084 & .135 & 1.233 & .220 & \\
\hline Access to the Internet at home & & .009 & .301 & .002 & .028 & .977 & $.115^{*}$ \\
\hline Experience with using the Internet & & .832 & .602 & .136 & 1.381 & .170 & \\
\hline Length of time using the Internet & & $-.050-$ & .092 & -.059 & $-.538-$ & .592 & \\
\hline Attitudes & & .567 & .281 & .201 & 2.019 & .045 & \\
\hline
\end{tabular}

$* P<.05$

\section{Discussion}

The current study indicated that home Internet access is available for the majority of participating Saudi students which is in line with previous findings in Saudi Arabia (Al Otaibi, 2012; Aldebasi \& Ahmed, 2013; Ali, 2013; Almalki, 2011). Similarly, the majority of participating students had considerable Internet experience, with almost half of them using the Internet for more than four years. This finding is in contrast with the original study from which this questionnaire was taken, bearing in mind the context and age of students (Tsai et al., 2001). The students participating in the present investigation had greater experience with using the Internet, but the decade between the two studies as well as the difference of the educational level may well explain this difference in experience. However, the findings of the present study are consistent with previous findings in Saudi Arabia which indicated that the majority of students had great Internet experience (Ali, 2013; Oshan \& Khudair, 2008).

In regard to student attitudes towards the Internet, the findings of the current study showed that students had positive attitudes toward using the Internet in general. These findings are in line with other studies in Saudi Arabia (Al Otaibi, 2012) and in other contexts (Abedalaziz et al., 2013; Al Mahmud, 2011; Hong et al., 2003; Israel, 2013; Luan et al., 2005; Peng et al., 2006; Rehman et al., 2010). Interestingly, the statistical findings of the present study have indicated that demographic variables including age, program of study, and year of study had no effect on student attitudes towards the Internet. Some of these findings seem to be compatible with those findings of Tuncer et al. (2013), who revealed no meaningful differences between student attitudes based on age and grade. Chou et al. (2011) also found no significant differences of undergraduates attitudes towards the Internet based on their age. Similarly in the same context, Abedalaziz et al. (2013) found that program of study had no effect on student attitudes towards the Internet, but younger students had significantly higher positive attitudes toward the Internet usage than older student.

The contradictory findings regarding the effect of student age can be attributed to the presence of a wide age gap among student categories (less than 30, 30 to 40, more than 40) in Abedalaziz et al.'s study whereas all students in the present study fit into the youngest age category of that study. The apparent lack of effect of the program of study on student Internet attitudes in the present findings is in contrast to the findings of Hong et al. (2003) and Tuncer et al. (2013), who found significant differences between student attitudes towards the Internet based on student field of study. It may be that the significant differences detected in Hong et al. (2003) and Tuncer et al. (2013) studies were due to the involvment of students from multiple fields of study in which some of them were more likely to be exposed to use the Internet for course related activities, whereas students in the present study were studying a number of programs within a single field of study, education.

In regards to the statistical differences between student attitudes based on study years/grade, the statistical test results indicated that participating students had similar attitudes towards using the Internet regardless of their year of study which is in line with previous findings related to undergraduate students (Chou et al., 2011; Tuncer et al., 2013). This finding may indicate that student Internet experience level may have greater impact than university information technology courses in forming their attitudes towards the Internet. However, this finding is inconsistent with Chou et al. (2011) and Peng et al. (2006), who found students at the advanced-grade level had a stronger tendency to frequently use the Internet and had higher positive attitudes towards the Internet than students at the lower-grade level. The inconsistent findings could be attributed to the involvement of graduate students in the studies conducted 
by Chou et al. (2011) and Peng et al. (2006), whereas this was not the case of the present study. Graduate research studies may expose them more deeply to the Internet than their undergraduate counterparts.

The present study indicated that students who have home Internet access or greater prior experience with it had significantly more positive attitudes towards using the Internet, which may explain the positive attitudes that emerged. As discussed earlier, many participating students could access the Internet at home and appeared to be experienced with using it. This important finding is in line with a number of studies that have shown positive effect of Internet accessibility and/or experience on student attitudes towards it in Saudi Arabia (Al-Arfaj, 2001; Al Otaibi, 2012; Alaugab, 2007; Oshan \& Khudair, 2008) and in other contexts (Al Mahmud, 2011; Luan et al., 2005; Tekynarslan, 2008; Tsai et al., 2001).

The present study suggested that, while there was no significant difference between student access to the Internet at home and the length of experience with using the Internet, students on the first year of study were significantly more experienced than those in the fourth year of study. This finding may be attributed to the existence of a small number fourth year students with no Internet experience, but it could be also attributed to the domination of traditional learning as university programs progress (Ageel, 2011; Al-Zahrani, 2015; Alebaikan \& Troudi, 2010a).

The current study indicated that students preferred the implementation of blended learning. These findings are consistent with other findings in the same context (AlAbdulkarim \& Albarrak, 2015; Alseweed, 2013; Ja'ashan, 2015) and in another Arabic contexts (Shantakumari \& Sajith, 2015), which have found that students perceived blended learning positively. Significantly, students in the fourth year showed stronger preference for the implementation of blended learning than those in the first year of study. Interestingly, the students did not favour simply traditional or online learning rather they preferred to divide study time equally between the two approaches. Similarly, student responses, both explicitly and implicitly, advocated the implementation of blended learning (see Table 6 and Section 5.6). These findings are in line with other research that indicated student preference for blended learning over other learning approaches in Saudi Arabia (Alseweed, 2013; Mohandes et al., 2006) and elsewhere (Tang \& Byrne, 2007). It might be suggested that students in the fourth year of study were more interested to the implementation of blended learning due to the long experience they had with traditional learning and their desire to study through a more effective learning approach. The qualitative findings also confirmed the domination of traditional learning which is in line with findings of other studies in the same context (Ageel, 2011; Al-Zahrani, 2015; Alebaikan \& Troudi, 2010a).

Students who were older, in the fourth year of study, or had higher positive attitudes towards the Internet were more positive about implementing blended learning and this persisted regardless their program of study. This contrasts with Shantakumari and Sajith (2015), who found significant differences of student perception of blended learning based on course enrolment and similar perceptions of blended learning based on age, even with substantial difference in student ages. It would appear from the present study that blended learning makes study more flexible for those students who have other life commitments in their final year of study. However, it is in line with the findings of Tekynarslan (2008), who found more positive attitudes were associated with greater preference for learning approaches that utilise the Internet. Although, student experience had a positive effect on their attitudes towards the Internet, it had no effect on their preference for implementing blended learning. Importantly, student attitudes towards the Internet appeared to have a potential effect on their preference of implementing blended learning. Accordingly, it can be argued that student experience with using the Internet has an indirect effect on their preference for implementation of blended learning, since it influences their attitudes towards the Internet. All in all, this supports the importance of appropriate attitudes for learning when the Internet is utilised as noted by $\mathrm{Wu}$ and Tsai (2006).

\section{Conclusion and Implications}

Experience with, and attitudes towards, the Internet are likely to affect student adoption of new learning approaches, particularly when Internet applications are used in blended learning environments. The relationships of demographic variables including age, program of study, and study year were analysed in this study with regard to student attitudes towards the Internet as well to student preference for the implementation of blended learning. Likewise, the relationships of experience variables including the accessibility to the Internet at home, having prior experience with using the Internet, and the length of this prior experience were analysed. Findings of this study have implications for higher education institutions, academic staff, instructional designer, researchers, and the community.

Findings from the present study have indicated that institutional support should be provided to make the Internet available and accessible to all students within the university campuses, for example through provision of 
appropriately equipped computer labs. Institutions might also periodically evaluate student experience with, and attitudes towards, using the Internet and provide students with such support as seems necessary at the time. Twenty-first century use of technology to enhance teaching and learning could make this particularly important. The present study suggests that contemporary Saudi university students are less interested in traditional learning or receiving their education entirely online, than they are in the mixture of traditional and online learning that characterises the blended approach. The Internet is likely to become an increasingly important way for students to stay up to date with new information as it emerges. This may well affect the design of future curriculum and this study suggests that instructional designers need to take into account student preference for one learning approach over another.

This paper began with recognition of the international base for developments in the digital learning space. The literature and results presented here should encourage researchers to establish comparative studies in different cultures and languages. Investigation of similar issues in varying contexts is very likely to illuminate both the issues and the cultural contexts. Finally, the community within the Saudi context should also recognise the benefit of using the Internet for educational purposes and make it accessible at home for university students, even if that has to be monitored due to cultural or religious barriers.

\section{Acknowledgements}

This study was funded by the Ministry of Higher Education in Saudi Arabia. Special thanks go to the first author's colleagues and friends who have facilitated the data collection process and have given their valuable time to translate the questionnaire. Special thanks also go to those students who voluntary have participated in this study.

\section{References}

Abedalaziz, N., Jamaluddin, S., \& Leng, C. H. (2013). Measuring attitudes toward computer and Internet usage among postgraduate students in Malaysia. The Turkish Online Journal of Educational Technology, 12(2), 200-216.

Ageel, M. (2011). The ICT proficiencies of university teachers in Saudi Arabia: A case study to identify challenges and encouragements. Hummingbird, University of Southampton's Doctoral Research Journal, 2, 55-60.

Al Mahmud, A. (2011). Students' attitudes towards Internet: A study on private universities of Bangladesh. European Journal of Business and Management, 3(6), 9-19.

Al Otaibi, K. N. (2012). Attitudes towards the use of the Internet. Psychology Research, 2(3), 151-159.

AlAbdulkarim, L. M., \& Albarrak, A. I. (2015, 12-14 October). Students' attitudes and satisfaction towards blended learning in the Health Sciences. Paper presented at the International Conference on Advances in Education and Social Sciences, Istanbul, Turkey.

Al-Arfaj, A. H. (2001). The perception of college students in Saudi Arabia towards distance Web-based instruction. Unpublished doctoral dissertation, Ohio University, Athens, Ohio, United States.

Alaugab, A. M. (2007). Benefits, barriers, and attitudes of Saudi female faculty and students toward online learning in higher education. Unpublished doctoral dissertation, University of Kansas, Lawrence, Kansas, United States.

Aldebasi, Y. H., \& Ahmed, M. I. (2013). Computer and Internet utilization among the medical students in Qassim University, Saudi Arabia. Journal of Clinical and Diagnostic Research, 7(6), 1105-1108. https://doi.org/10.7860/jcdr/2013/5891.3092

Alebaikan, R. (2010). Perceptions of blended learning in Saudi universities. Unpublished doctoral dissertation, University of Exeter, United Kingdom, Exeter.

Alebaikan, R., \& Troudi, S. (2010a). Blended learning in Saudi universities: Challenges and perspectives. Research in Learning Technology, 18(1), 49-59. https://doi.org/10.1080/09687761003657614

Alhareth, Y. A. (2013). E-learning contribution to the enhancement of higher education opportunities for women in Saudi Arabia (Pilot study). US-China Education Review A, 3(9), 637-648.

Ali, M. M. (2013). Internet usage among students and teachers: An exploratory study. International Journal of Advanced Research in Computer Science and Software Engineering, 3(6), 125-135.

Almalki, A. M. (2011). Blended learning in higher education in Saudi Arabia: A study of Umm Al-Qura University. Unpublished doctoral dissertation, RMIT University, Melbourne, Victoria, Australia. 
Alseweed, M. A. (2013). Students' achievement and attitudes toward using traditional learning, blended learning, and virtual classes learning in teaching and learning at the university level. Studies in Literature and Language, 6(1), 65-73.

Alshahrani, S., \& Ward, R. (2014, February). Shifting from traditional approaches of teaching to a blended learning approach; challenges and possible solutions. Paper presented at the 7th Saudi Students Conference-UK, Edinburgh, United Kingdom.

Alshawi, A., \& Alwabil, A. (2013). Internet usage by faculty in Saudi higher education. International Journal of Computer Science Issues, 10(3), 1694-0814.

Al-Zahrani, A. M. (2015). Enriching professional practice with digital technologies: Faculty performance indicators and training needs in Saudi higher education. International Journal of Instructional Technology and Distance Learning, 12(1), 44-57.

Brace, N., Kemp, R., \& Snelgar, R. (2006). SPSS for psychologists (3rd ed.). Basingstoke, Hampshire, England: Palgrave Macmillan.

Chou, C., Wu, H.-C., \& Chen, C.-H. (2011). Re-visiting college students' attitudes toward the Internet-based on a 6-T model: Gender and grade level difference. Computers \& Education, 56(4), 939-947. https://doi.org/10.1016/j.compedu.2010.11.004

Cohen, J. (1988). Statistical power analysis for the behavioral sciences (2nd ed.). Hillsdale, NJ: Lawrence Erlbaum Associates.

Communications and Information Technology Commission. (2009). Computer and Internet usage in the Kingdom of Saudi Arabia. Riyadh, Saudi Arabia: Author.

Creswell, J. W. (2012). Educational research planning, conducting and evaluating quantitative and qualitative research (4th ed.). Boston: Pearson.

Dörnyei, Z. (2003). Questionnaires in second language research: Construction, administration, and processing. Mahwah, N.J.: Lawrence Erlbaum Associates.

Duggan, A., Hess, B., Morgan, D., Kim, S., \& Wilson, K. (1999, April). Measuring students' attitudes toward educational use of the Internet. Paper presented at the Annual Conference of the American Educational Research Association, Montreal, Canada.

Duggan, A., Hess, B., Morgan, D., Kim, S., \& Wilson, K. (2001). Measuring students' attitudes toward educational use of the Internet. Journal of Educational Computing Research, 25(3), 267-281. https://doi.org/10.2190/GTFB-4D6U-YCAX-UV91

Field, A. P. (2009). Discovering statistics using SPSS (3rd ed.). London: Sage.

Garrison, D. R., \& Vaughan, N. D. (2008). Blended learning in higher education: Framework, principles, and guidelines. San Francisco: Jossey-Bass.

Graham, C. R. (2006). Blended learning systems: Definitions, current trends and future directions. In C. J. Bonk \& C. R. Graham (Eds.), The handbook of blended learning: Global perspectives, local designs (pp. 3-21). San Francisco: John Wiley \& Sons.

Graham, C. R. (2008). Blended learning models. In M. Khosrow-Pour (Ed.), Encyclopedia of information science and technology (Vol. 2, pp. 375-382). Hershey, PA: IGI Global.

Güzer, B., \& Caner, H. (2014). The past, present and future of blended learning: An in depth analysis of literature. Procedia - Social and Behavioral Sciences, 116, 4596-4603. https://doi.org/10.1016/j.sbspro.2014.01.992

Hong, K.-S., Ridzuan, A. A., \& Kuek, M.-K. (2003). Students' attitudes toward the use of the Internet for learning: A study at a university in Malaysia. Educational Technology \& Society, 6(2), 45-49.

Israel, O. (2013). Attitude of undergraduates towards educational usage of the Internet: A case of library schools in Delta and Edo States of Nigeria. International Journal of Science and Technology Educational Research, 4(4), 57-62.

Ja'ashan, M. H. (2015). Perceptions and attitudes towards blended learning for English courses: A case study of students at University of Bisha. English Language Teaching, 8(9), 40-50.

Johnson, B., \& Christensen, L. (2014). Educational research: Quantitative, qualitative, and mixed approaches (5th 
ed.). Thousand Oaks, CA: Sage.

Luan, W. S., Fung, N. S., Nawawi, M., \& Hong, T. S. (2005). Experienced and inexperienced Internet users among pre-service teachers: Their use and attitudes toward the Internet. Educational Technology \& Society, 8(1), 90-103.

Lukman, R., \& Krajnc, M. (2012). Exploring non-traditional learning mthods in virtual and real-world environments. Educational Technology \& Society, 15(1), 237-247.

Madini, A. A., \& de Nooy, J. (2014). Cross-gender communication in a Saudi Arabian Internet discussion forum: Opportunities, attitudes, and reactions. Convergence: The International Journal of Research into New Media Technologies, 1-17.

Miliany, K. (2014). The use of TV and the Internet in the social context. International Journal of Social, Education, Economics and Management Engineering, 8(10), 3160-3167.

Mohandes, M., Dawoud, M., Amoudi, S. A., \& Hussain, A. A. (2006). Online development of digital logic design course. Paper presented at the 2nd International Conference on Information \& Communication Technologies: From Theory to Applications. https://doi.org/10.1109/ictta.2006.1684342

Morse, B. J., Gullekson, N. L., Morris, S. A., \& Popovich, P. M. (2011). The development of a general Internet attitudes scale. Computers in Human Behavior, 27(1), 480-489. https://doi.org/10.1016/j.chb.2010.09.016

Muijs, D. (2004). Doing quantitative research in education: With SPSS. London: Sage. https://doi.org/10.4135/9781849209014

Oshan, M. S., \& Khudair, A. A. (2008). King Saud University students’ attitude towards the Internet: Experience and gender issues. Information Studies, 3, 1-29.

Pallant, J. F. (2011). SPSS survival manual: A step by step guide to data analysis using SPSS (4th ed.). Crows Nest, NSW, Australia: Allen \& Unwin.

Peng, H., Tsai, C.-C., \& Wu, Y.-T. (2006). University students' self-efficacy and their attitudes toward the Internet: The role of students' perceptions of the Internet. Educational Studies, 32(1), 73-86. https://doi.org/10.1080/03055690500416025

Rehman, K. U., Hunjra, A. I., Safwan, N., \& Ahmad, A. (2010). Students’ Attitude towards the Uses of Internet. International Journal of Business and Management, 5(6), 46-55. https://doi.org/10.5539/ijbm.v5n6p46

Robertson, M., \& Al-Zahrani, A. (2012). Self-efficacy and ICT integration into initial teacher education in Saudi Arabia: Matching policy with practice. Australasian Journal of Educational Technology, 28(7), $1136-1151$. https://doi.org/10.14742/ajet.793

Shantakumari, N., \& Sajith, P. (2015). Blended learning: The student viewpoint. Annals of Medical and Health Sciences Research, 5(5), 323-328. https://doi.org/10.4103/2141-9248.165248

Simsim, M. T. (2011). Internet usage and user preferences in Saudi Arabia. Journal of King Saud University Engineering Sciences, 23(2), 101-107. https://doi.org/10.1016/j.jksues.2011.03.006

Susan, Y. M. (2000). Measurement in a cross-cultural environment: Survey translation issues. Qualitative Market Research: An International Journal, 3(2), 74-81. https://doi.org/10.1108/13522750010322070

Tang, M., \& Byrne, R. (2007). Regular versus online versus blended: A qualitative description of the advantages of the electronic modes and a quantitative evaluation. International Journal on ELearning, 6(2), 257-266.

Tekynarslan, E. (2008). Faculty of education students' attitudes toward Internet and implications for online learning. Abant İzzet Baysal Üniversitesi Eğitim Fakültesi Dergisi, 8(1), 67-82.

Tsai, C.-C., Lin, S. S. J., \& Tsai, M.-J. (2001). Developing an Internet attitude scale for high school students. Computers \& Education, 37(1), 41-51. https://doi.org/10.1016/S0360-1315(01)00033-1

Tuncer, M., Dogan, Y., \& Tanas, R. (2013). Vocational school atudents’ attitudes towards Internet. Procedia - Social and Behavioral Sciences, 103, 1303-1308. https://doi.org/10.1016/j.sbspro.2013.10.460

Wiebe, E. N., Shaver, E., \& Wogalter, M. S. (2002). Attitudes about the Internet: Implications for use in education. Journal of Educational Technology Systems, 31(2), 143-156. https://doi.org/10.2190/L7UB-G81U-0MD5-3FK7

Wu, Y.-T., \& Tsai, C.-C. (2006). University students’ Internet attitudes and Internet self-efficacy: A study at three universities in Taiwan. Cyberpsychology \& Behavior, 9(4), 441-450. https://doi.org/10.1089/cpb.2006.9.441 
Zhang, Y. (2007). Development and validation of an Internet use attitude scale. Computers \& Education, 49(2), 243-253. https://doi.org/10.1016/j.compedu.2005.05.005 